\title{
A PERSONALITY DEVELOPMENT PROGRESS IN BOSS AND SECRETARY RELATIONSHIP AT BUSINESS ORGANIZATIONS
}

\author{
Dr. C K GOMATHY, Ms. M.S.L. ALEKHYA, MS. N. RAMYA, Ms. K.N.S. SNIGDHA \\ Sri Chandrasekharendra Saraswathi Viswa Mahavidyalaya, Kanchipuram
}

\begin{abstract}
The study centered on recognizing the major instincts/factors that persuade a solid relationship between a Boss and Secretary within the working environment. The populace of the think about comprised of 60 secretarial staff. There was no test, drawn from the consideration, the total populace was utilized. Four inquire-about questions were defined which guided the consider. There was no speculation, A 21- Thing organized survey was created, validated, and tried for its unwavering quality. Rates and frequencies were utilized to reply to the investigate questions. The major discoveries of the investigation were:

1. Partnering with a boss or deputizing a boss in the workplace inspires or fosters a stronger instinct between the boss and secretary.

2. The secretary's part in managing her boss's daily tasks strengthens their bond.

3. The tactfulness of a secretary and the way he/she psychologies callers and upsets people improves their friendly relationship.

4. The secretary's instincts for arranging or fulfilling his or her boss's or executives' goals are quite important. It was determined that certain secretaries have numerous issues, such as a lack of job satisfaction, motivation, and satisfaction, and that they are excluded in management decision-making. There isn't enough current technology in the office.

Secretaries who are resourceful in their ability to implement mature judgment are valued by their bosses. It was suggested that secretaries who are skilled in demonstrating their abilities be considered. Bosses, on the other hand, should hire communicative secretaries and possessing a pleasant manner, being polite and tactful, arriving on time to duty positions, and engaging in psychology activities. All of these things contribute to a healthy and pleasant relationship between the boss and the secretary.
\end{abstract}


Keywords: Personality development, Boss Vs Secretary Communication, Work-place behavior, Business organization relationship.

\section{INTRODUCTION}

Business owners and managers are constantly in need of data on which to make their decisions to achieve the best results. As a result, knowledgeable and effective information analysts and communication aides are always in demand. The particular progress of any kind of organization depends exclusively on the high quality from the choice-making, and selections that achieve the preferred result is the direct function associated with the quality plus timeliness info accessible to the Professional, he cannot; yet pay attention to his information experts.

Eni claims (1991). The importance of secretaries in every organization cannot be overstated. According to Eni (1991), a secretary is "a member of the clerical staff whose core activities are involved with the production, presentation, and preservation of correspondence and communication of all types inside the company and to its consumers." As a result, the Executive Assistant guarantees that official information is organized and presented in such a way that the manager gains the most from his decisions.

It's almost impossible to provide all of the secretarial abilities that a boss would require, let alone the personal qualities that a good secretary possesses, such as PUNCTUALITY, RELIABILITY, DISCRETION, TACT, CORDIAL, and so on. You must become an important member of the management team by learning the company's policies as well as your boss's. Capable of playing a vital and active role in his work. Given the importance of information and its management to the organization's success or failure, and hence to the Manager, he cannot be concerned about who becomes his secretary. Furthermore, the secretary is the executive's or boss's alter ego, as well as the organization as a whole.

As a result, the boss's relationship with his secretary is one of the "Partnership" in the office. That collaboration might be an ongoing adventure that provides tremendous job satisfaction and leads to progress for both the boss and the secretary.

The word "Secretarial Field" is one in which numerous individuals both male and female genders single or hitched are interested. However numerous individuals after choosing it as a career come up short to meet up the demands of the chief executives. The career has been recording a huge number of understudies within the polytechnics and colleges considering secretarial thinks about presently known as Office Technology and 
Management (OTM). It is within the light of the over, that this inquiry about work was carried out to recognize the instincts/factors that persuade the chief executives in selecting the individual secretaries.

Without mutual understanding between the boss and secretary, no organization can run efficiently. When they are working, both the boss and the secretary must regard themselves as partners in growth. They must be able to trust themselves in the organization. They should have a friendly connection that aids in the growth of the office.

Besides, there should be a rule built up by the company to direct the boss and secretary in their activities to construct a great working relationship. This rule is regularly based on the thought of participation, in which they recognize that the full work cannot be completed without their cooperation. The mutual association leads to the fulfillment results of the assistance. In each organization, client fulfillment is basic since it is regularly passed on to clients, giving the appearance that work is being done.

When one of the bosses or secretaries is dissatisfied with the other's job performance, the relationship's goal is threatened. Some managers, for example, who are stringent about allocating assignments, may force their secretaries to do work for a week in one day. When they fail to satisfy such a need, their supervisor becomes quite hostile toward them. This mindset is harmful to their working relationship and the efficiency of the organization.

The manager should be aware that the secretary is a human being, not a machine, who is human and flawed. According to Elegido (1996), every time we choose to ignore other people's well-being, we lessen the relevance of that well-being for us and the strength of the links that bind us to them by at least a small amount. Choosing to act in this manner also diminishes the value we place on behaving based on information and understanding rather than being swept away by emotional outbursts.

Secretaries, on the other hand, should have high regard for their employer by performing the tasks allocated to them properly to avoid making mistakes that could result in the firm losing money. The boss and secretary are like the cornerstones of any organization, and it would be impossible to function without them. As a result, they must overcome any obstacles that may prevent their relationship from being rewarding, as the relationship should be beneficial to the organization in terms of increased productivity, revenue, and office expansion. According to Elegido (1996), good intentions are not enough when it comes to promoting human fulfillment. 


\section{PROBLEM STATEMENT}

Some bosses do not recognize the importance of secretaries in the organization, even though they play an important role. When bosses leave everything to their secretaries, they can exhibit a nonchalant attitude toward work. Furthermore, the boss and secretary's mutual interaction does not typically provide satisfaction, which impedes the office's growth.

\section{PURPOSE OF STUDY}

The study's fundamental objective was to decide "the instinctual that persuade, as well as the boss-secretary relationship within the work environment." The study's targets were to:

1. Impulses recognize the secretaries who can offer assistance he accomplishes his executive's goals.

2. Decide the secretary's part in sorting out her boss's everyday responsibilities.

3. Decide the secretary's thoughtfulness and capacity to deal with angry callers within the workplace.

4. To decide the variables that progress the relationship between the boss and the secretary.

\subsection{RESEARCH QUESTIONS}

The study was guided by four research questions.

1. What is the secretary's instinct for attaining his executive's goals through cooperation?

2. What function does the secretary play in her Boss's Day-to-day tasks?

3. How delicate is the secretary when it comes to psychologizing and dealing with upset customers? Who are the organization's callers?

4. What are the factors that improve the relationship between the boss and the secretary in the workplace?

\section{METHODOLOGY}

This study's survey design was deemed suitable. The survey solicited the opinions of secretaries from various businesses in Andhra Pradesh State on the characteristics that improve the boss-secretary relationship at work. 
Because survey design focuses on individuals, their views, opinions, attitudes, and behaviors, it was judged the most acceptable method for acquiring the data needed for the study (Best 1984).

To answer the four study questions, the data received from respondents was evaluated using percentages of items in the part B of the questionnaires.

For the usage of percentages, there is a formula.

Percentage $(\%)=\mathrm{Fx} 100 / \mathrm{N}=1$

Where $\mathrm{F}$ is the total number of frequencies multiplied by 100 .

$\mathrm{N}=$ Number of Respondents $=1$

Decision Rule: - Any item with a percentage score of $50 \%$ or more is considered AGREE. DISAGREED was defined as an item having a score of less than $50 \%$.

\section{Research Question one:}

What are the elements that influence the boss-secretary relationship at work?

Table 1 shows the data related to this research issue.

Responses to elements that improve the boss/secretary relationship at work.

\begin{tabular}{|c|c|c|c|}
\hline S. NO & OPTIONS & FREQUENCY & PERCENTAGE (\%) \\
\hline 1 & Partnership in office & 25 & 41.7 \\
\hline 2 & Your Secretarial skills & 20 & 33.3 \\
\hline 3 & Being Punchier to & 10 & 10.7 \\
\hline 4 & work & & 8.3 \\
\hline & Organizing your Boss & 5 & 100 \\
\hline
\end{tabular}

TABLE 1: Elements that improve the boss/secretary relationship at work

According to the above table, the majority of respondents believed that 'Office Partnership Enhances a Secretary and His Boss'. 
International Journal of Scientific Research in Engineering and Management (IJSREM)

Volume: 06 Issue: 02 | Feb - 2022

ISSN: 2582-3930

\begin{tabular}{|c|c|c|c|c|c|}
\hline $\begin{array}{c}\text { S. } \\
\text { NO }\end{array}$ & ITEMS & FREQUENCY & $\begin{array}{c}\text { \% } \\
\text { AGREED }\end{array}$ & $\begin{array}{c}\text { FREQUENCY } \\
\text { NO }\end{array}$ & \%DISAGREED \\
\hline 1 & $\begin{array}{c}\text { Bosses engage secretaries } \\
\text { that are discrete and } \\
\text { dedicated to work }\end{array}$ & 45 & 95.2 & 15 & \\
\hline 2 & $\begin{array}{c}\text { Bosses engage secretaries } \\
\text { that possess business sense } \\
\text { of Initiative }\end{array}$ & 30 & 50 & 30 & \\
\hline 3 & $\begin{array}{c}\text { Bosses like secretaries that } \\
\text { have a pleasant manner }\end{array}$ & 59 & 97.5 & & \\
\hline 4 & $\begin{array}{c}\text { Most bosses like secretaries } \\
\text { with proficient secretarial } \\
\text { skill }\end{array}$ & 58 & 95 & & \\
\hline
\end{tabular}

\section{Research Question Two:}

What is the secretary's corporate instinct in attaining his Executive's goals?

Table 2 contains the information needed to answer this question.

TABLE 2: Secretary's corporate instinct in attaining his Executive's goals

\section{Research Question Three:}

What is the secretary's role in organizing her boss's daily tasks?

Table 3 displays the data related to this research issue.

\begin{tabular}{|c|c|c|c|c|c|}
\hline SNO & ITEMS & FREQUENCY & $\begin{array}{c}\text { \% } \\
\text { AGREED }\end{array}$ & $\begin{array}{c}\text { FREQUENCY } \\
\text { NO }\end{array}$ & DISAGREED \\
\hline 1 & $\begin{array}{c}\text { Deputing for the boss } \\
\text { when he is Not on sit }\end{array}$ & 58 & 95 & 2 & 5 \\
\hline 2 & Provision of writing & 30 & 50 & 30 & 50 \\
\hline 3 & meceiving Visitors & 40 & 80 & 20 & 20 \\
\hline 4 & Planning Travels & 20 & 20 & 40 & 80 \\
\hline
\end{tabular}

TABLE 3: Secretary's role in organizing his/her boss's daily tasks 


\section{Research Question Four:}

How tactful is the secretary when it comes to psychologizing and dealing with irate callers in the office?

Table four contains the information related to this inquiry.

$\mathrm{N}=60$

\begin{tabular}{|c|c|c|c|c|c|}
\hline S. NO & ITEMS & YES & $\%$ & NO & $\%$ \\
\hline 1 & By being polite & $\checkmark$ & 100 & $x$ & - \\
\hline 2 & Having Business Sense of initiative & $\checkmark$ & 100 & $x$ & - \\
\hline 3 & $\begin{array}{l}\text { Ask Intelligent questions and listens attentively to } \\
\text { callers }\end{array}$ & $\checkmark$ & 100 & $x$ & - \\
\hline 4 & $\begin{array}{c}\text { Being able to plan co-ordinate and having } \\
\text { organizing skills }\end{array}$ & $\checkmark$ & 100 & $x$ & - \\
\hline
\end{tabular}

TABLE 4: Secretary when it comes to psychologizing and dealing with irate callers in the office

\section{RESULTS \& DISCUSSIONS}

When asked about the characteristics that improve the boss/secretary relationship at work, it was discovered that demonstrating the secretaries' abilities is critical. According to Eltori (1982) "The Boss anticipated the secretary's abilities to be excellent " shown properly and without errors, and is anticipated to be typing at least 60 words per minute, and 120 words per minute for shorthand dictations the number of words per minute The secretary's desire for cooperation in attaining his goals is instinctive. The executive's goals are achieved when he or she has access to skilled secretaries. Once in a while, having a nice attitude might assist you in reaching your objectives.

The majority of respondents agreed that the secretary's role in organizing the boss's schedule of duties, such as planning journeys or tours, receiving information, etc., is one of the factors that enhances the boss/secretary relationship.

The most important thing for a secretary is to be of significant support to her/his boss "Eni" (1990). 
Because most bosses prefer secretaries with proficient performance skills, the secretary's qualification has an impact on the field of work. These credentials will enable the secretary to be fully prepared, both in terms of shorthand and typing, and, of course, to manage the organization's affairs with tact. Finally, the psychologies irate callers in the workplace by being pleasant, having a business sense of initiative, asking intelligent questions and listening to directions, planning, coordinating, and organizing abilities.

All of these things add up to elements that strengthen a boss's feelings about his or her secretary at work.

\section{CONCULSION}

The following conclusions were drawn based on the study's findings:

1. Most bosses want the secretary to demonstrate all of her secretarial abilities. 2. The secretary's understanding of English and word processing should be adequate.

3. Bosses like secretaries who are more organized and have the secretary's sense for cooperation to be excellent and appealing in attaining his boss's goals.

4. Bosses admire secretaries who are resourceful in their decision-making abilities.

\section{REFERENCES}

[1] Eleaner M. and little J. (1980). The successful Secretary Estover Pay mouth pg. 6,76.

[2] Elegido.,(1996) Secretaryship as Career.The secretary Vol.50.No.6,pg.19- 26.

[3] Eltori., (1982) The secretaries role in Organizing her Boss and his Daily Duties.

[4] Macdonald E.E; (1998). The Developing Role of the Secretary, Education and Training, Vol. 30,850 NO6.pg. 15-19.

[5] C.K.Gomathy.(2010),"Cloud Computing: Business Management for Effective Service Oriented Architecture" International Journal of Power Control Signal and Computation (IJPCSC), Volume 1, Issue IV, Oct - Dec 2010, P.No:22-27, ISSN: 0976-268X .

[6] Dr.C K Gomathy, Article: A Study on the recent Advancements in Online Surveying , International Journal of Emerging technologies and Innovative Research ( JETIR ) Volume 5 | Issue 11 | ISSN : 23495162, P.No:327-331, Nov-2018

[7] Dr.C.K.Gomathy,C K Hemalatha, Article: A Study On Employee Safety And Health Management International Research Journal Of Engineering And Technology (Irjet)- Volume: 08 Issue: 04 | Apr 2021

[8] Dr.C K Gomathy, Article: A Study on the Effect of Digital Literacy and information Management, IAETSD Journal For Advanced Research In Applied Sciences, Volume 7 Issue 3, P.No-51-57, ISSN NO: 2279-543X,Mar/2018

[9] Dr.C K Gomathy, Article: An Effective Innovation Technology In Enhancing Teaching And Learning Of Knowledge Using Ict Methods, International Journal Of Contemporary Research In Computer Science And Technology (Ijcrcst) E-Issn: 2395-5325 Volume3, Issue 4,P.No-10-13, April ’2017 
[10] Dr.C K Gomathy, Article: Supply chain-Impact of importance and Technology in Software Release Management, International Journal of Scientific Research in Computer Science Engineering and Information Technology ( IJSRCSEIT ) Volume 3 | Issue 6 | ISSN : 2456-3307, P.No:1-4, July-2018.

\section{AUTHOR'S PROFILE}

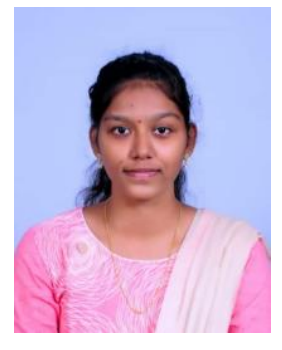

Ms. M.S.L. ALEKHYA, Student, B.E. (Computer Science and Engineering), Sri Chandrasekharendra Saraswathi Viswa Maha Vidhyalaya, Enathur, Kanchipuram, India. Her area of interest in Human Resources Development.

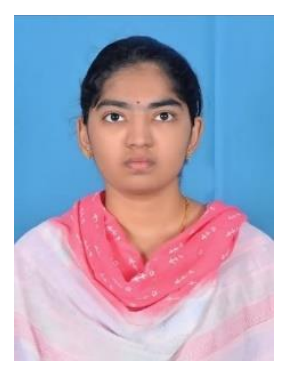

Ms. N. RAMYA, Student, B.E. (Computer Science and Engineering), Sri Chandrasekharendra Saraswathi Viswa Maha Vidhyalaya, Enathur, Kanchipuram, India. Her area of interest in Human Resources Development.

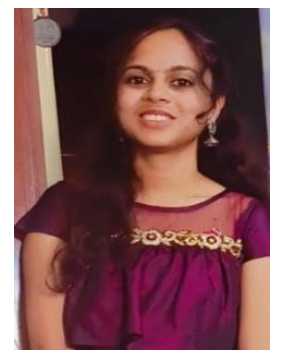

Ms. K.N.S. SNIGDHA, Student, B.E. (Computer Science and Engineering), Sri Chandrasekharendra Saraswathi Viswa Maha Vidhyalaya, Enathur, Kanchipuram, India. Her area of interest in Human Resources Development.

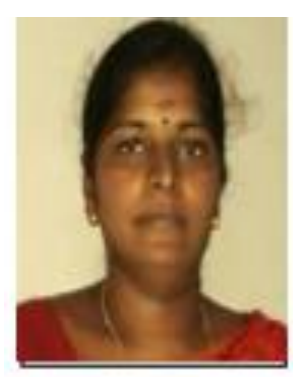

Dr. C.K.Gomathy is Assistant Professor in Computer Science and Engineering at Sri Chandrasekharendra Saraswathi Viswa Maha Vidyalaya, Enathur, Kanchipuram, India. Her area of interest in Software Engineering Web Services, Knowledge Management and IOT. 